\title{
Involvement of capsular polysaccharide via a TLR2/NF-kB pathway in Vibrio vulnificus-induced IL-8 secretion of human intestinal epithelial cells
}

\author{
BYUNG CHEOL LEE ${ }^{1}$, MYUN SOO KIM ${ }^{1}$, SANG HO CHOI ${ }^{2}$ and TAE SUNG KIM ${ }^{1}$ \\ ${ }^{1}$ Division of Life Sciences, School of Life Sciences and Biotechnology, Korea University, Seoul 136-701; \\ ${ }^{2}$ National Research Laboratory of Molecular Microbiology and Toxicology, Department of \\ Agricultural Biotechnology, Seoul National University, Seoul 151-921, Republic of Korea
}

Received November 4, 2009; Accepted January 5, 2010

DOI: 10.3892/ijmm_00000380

\begin{abstract}
In a previous study, we reported that a $w b p P$ gene mutation in Vibrio vulnificus was significantly impaired in its ability to synthesize surface capsular polysaccharide (CPS). In this study, we evaluated the functions of the $V$. vulnificus capsular polysaccharide on interleukin (IL)-8 production, as well as its underlying mechanisms in human intestinal epithelial cells. The CPS-defective $w b p P$ mutant induced significantly lower levels of IL-8 production, IL-8 gene promoter activation and NF- $\mathrm{B}$ activity in INT-407 cells than was noted with the wild-type or $w b p P$-complemented $V$. vulnificus. The expression levels of Toll-like receptor (TLR) 2 mRNA and protein were also found to be lower in INT-407 cells infected with the CPS-defective wbpP mutant than in those cells infected with the wild-type or the $w b p P$ complemented strains. Additionally, the treatment of INT-407 cells with anti-TLR2 antibody proved to significantly block IL-8 production and NF- $\mathrm{KB}$ minimal promoter activity induced by the wild-type or the $w b p P$-complemented strains. Furthermore, purified $V$. vulnificus CPS was found to significantly induce IL-8 production and NF- $\mathrm{KB}$ activation, both of which were inhibited upon the addition of the anti-TLR2 antibody. Taken together, these results demonstrate that $V$. vulnificus capsular polysaccharide is involved in the induction of IL-8 production of human intestinal epithelial cells via a TLR2/NF-кB-dependent pathway.
\end{abstract}

\section{Introduction}

Vibrio vulnificus is a gram-negative estuarine bacterium which has been identified as a significant human pathogen.

Correspondence to: Dr Tae Sung Kim, School of Life Sciences and Biotechnology, Korea University, Seoul 136-701, Republic of Korea

E-mail: tskim@korea.ac.kr

Key words: Vibrio vulnificus, capsular polysaccharide, interleukin-8, Toll-like receptor 2, nuclear factor- $\mathrm{KB}$, intestinal epithelial cell
V. vulnificus, when it is orally ingested via contaminated shellfish, reaches the intestine and invades the bloodstream across the intestinal mucosal barrier of the host. Wound infection or oral infection in susceptible individuals, such as those with chronic liver disease, can induce severe septicemia $(1,2)$. Mortality in septic patients exceeds $50 \%$ and can increase to more than $90 \%$. The majority of fatal cases are attributable to septic shock which results from a variety of virulence factors of $V$. vulnificus including lipopolysaccharide (LPS) (3), capsular polysaccharide (CPS) (4-6), siderophores (7), cytolysin (8), elastolytic protease (9), phospholipase $\mathrm{A}_{2}$ (10), RTX toxin (rtxA) (11) and flagella (12). These virulence factors may persistently activate the generation of proinflammatory mediators such as tumor necrosis factor- $\alpha$ from the affected host $(4,13,14)$. In particular, surface polysaccharides, including CPS and LPS, perform pivotal roles in the pathogenicity of gram-negative bacteria by assisting the bacteria in the evasion of host defenses $(4,15)$. CPS production is believed to constitute a primary virulence factor of $V$. vulnificus, which is essential for pathogenicity $(4,5)$. To date, capsular polysaccharide types among different isolates of $V$. vulnificus have been extensively studied, and more than 13 CPS have been identified by chromatographic analysis and NMR spectroscopy (16). However, although a substantial body of literature currently exists concerning the structural determination of the CPS from V. vulnificus $(17,18)$, several researchers have focused on the identification of the genes involved in $V$. vulnificus capsular polysaccharide expression $(19,20)$.

$w b p P$ is a member of the short-chain dehydrogenase/ reductase superfamily that encodes for a putative UDP- $N$ acetyl-D-glucosamine $\mathrm{C}_{4}$ epimerase $(21,22)$. A wbpP protein is required for the synthesis of UDP- $N$-acetyl-D-galactosaminuronic acid (UDP-GalNAcA) from UDP- $N$-acetyl-Dglucosamine (UDP-GlcNAc) via $\mathrm{C}_{4}$ epimerization and further dehydrogenation. UDP-GalNAcA is an important intermediate used for the biosynthesis of various uronic acid sugars of surface polysaccharides harboring GalNAcA or its derivatives. The biosynthetic pathways and molecular genetics of surface polysaccharide production have been previously evaluated in Pseudomonas aeruginosa as well as several other organisms 
(21). Recently, we reported that an isogenic mutation of the wbpP gene in $V$. vulnificus resulted in an impairment of its ability to synthesize CPS and to adhere to epithelial cells, and also induced a reduction of virulence in mice, thereby indicating that $w b p P$ is critical to both the pathogenesis and the capsular polysaccharide biosynthesis of $V$. vulnificus (22).

Interleukin-8 (IL-8) has been demonstrated to perform an important role in the pathogenesis of infectious diseases $(14,23)$. IL-8 is produced in immune and epithelial cells in response to microbial stimuli including exposure to Helicobacter pylori, Salmonella typhimurium, Escherichia coli and Vibrio cholerae, and its production is regulated via microbial and host factors including transcription factors and cell surface molecules such as Toll-like receptors (TLRs) $(24,25)$. We previously reported that $V$. vulnificus infection induced IL-8 production in human intestinal epithelial cells via $\mathrm{NF}-\kappa \mathrm{B}$ activation. The mutation of the NF- $\mathrm{BB}$ site within the IL-8 promoter has been demonstrated to result in a substantial reduction in IL-8 production in response to $V$. vulnificus infection, thereby underlining the critical importance of NF- $\mathrm{KB}$ in IL-8 production. Members of the TLR family are detected principally in mammalian immune cells including macrophages and dendritic cells, but are also expressed on many types of epithelial cells $(26,27)$. Upon the interaction of TLR with its ligands, the receptor initiates signaling cascades that lead to the transcription and secretion of anti-microbials, immune-modulating cytokines and chemokines.

In this study, we evaluated the functions of the capsular polysaccharide of $V$. vulnificus in the induction of IL-8 production, as well as its underlying mechanism in human intestinal epithelial cells. We demonstrated that the capsular polysaccharide of $V$. vulnificus is involved in the induction of IL-8 production of human intestinal epithelial cells via a TLR2/NF-кB-dependent pathway.

\section{Materials and methods}

Cell lines and cultures. The human intestinal epithelial cell line INT-407 was purchased from the American Type Culture Collection (ATCC, Manassas, VA, USA) and maintained at $37^{\circ} \mathrm{C}$ in $5 \% \mathrm{CO}_{2}$ in minimum essential medium (MEM) supplemented with $10 \%$ fetal bovine serum (Gibco BRL, Grand Island, NY, USA) and antibiotics (10 unit/ml penicillin $\mathrm{G}$ and $10 \mu \mathrm{g} / \mathrm{ml}$ streptomycin) (growth medium). Human embryonic kidney 293 (HEK293/Null), HEK293/ hTLR2/CD14 stably expressing hTLR2/CD14, and HEK293/ hTLR4/MD-2/CD14 cells stably expressing hTLR4/MD-2/ CD14 were kindly provided by Dr In-Hong Choi (Yonsei University, Seoul, Korea). The cells were maintained at $37^{\circ} \mathrm{C}$ in $5 \% \mathrm{CO}_{2}$ in DMEM supplemented with $10 \%$ fetal bovine serum and antibiotics (10 unit/ml penicillin G, $10 \mu \mathrm{g} / \mathrm{ml}$ streptomycin, $10 \mu \mathrm{g} / \mathrm{ml}$ blasticidin and $50 \mu \mathrm{g} / \mathrm{ml}$ Hygrogold).

Bacterial strain and growth conditions. V. vulnificus strain ATCC 29307 used in this study was purchased from the ATCC, and the capsular polysaccharide (CPS) defective$w b p P$ mutant and CPS-reproductive $w b p P$-complemented strains were generated as previously described (22). To inactivate wbpP in vitro, 1.2-kb nptI DNA conferring resistance to kanamycin was inserted into a unique Bam HI site present within the $w b p P$ open reading frame to produce pNY0421 [pDM4 (suicide vector) with wbpP::nptI; $\mathrm{Cm}^{\mathrm{r}}$ $\mathrm{Km}^{\mathrm{r}}$ ]. E. coli SM10 $\lambda$ pir (containing pNY0421) was used as a conjugal donor to generate the wbpP::nptI mutant of wildtype V. vulnificus, ATCC 29307, by homologous recombination. The conjugation and isolation of the transconjugants were conducted, and a double crossover, in which the wildtype $w b p P$ gene was replaced with the $w b p P:: n p t I$ allele, was confirmed by PCR. wbpP-complemented $V$. vulnificus was constructed by subcloning $w b p P$ amplified by PCR and digested with restriction enzymes (PstI/EcoRI) into the broad host-range vector pRK415 linearized with the same enzymes. The resulting plasmid was mobilized into the wbpP mutant $V$. vulnificus by conjugation. For the infection experiments, the bacteria were grown overnight at $30^{\circ} \mathrm{C}$ in Luria-Bertani medium supplemented with $2.0 \% \mathrm{NaCl}$ (LBS medium), diluted to $\sim 6 \times 10^{8} \mathrm{CFU} / \mathrm{ml}$ in LBS, centrifuged and then resuspended in antibiotic-free growth medium prior to infection into epithelial cells. Bacterial concentrations were confirmed via viable cell counts on LBS agar.

Infection protocol. Human intestinal epithelial INT-407 cells were infected with $V$. vulnificus as previously described (28). In brief, INT-407 cells were grown in culture flasks at $37^{\circ} \mathrm{C}$ in a $5 \% \mathrm{CO}_{2}$ incubator. The cells $\left(5 \times 10^{5} /\right.$ well $)$ were seeded onto 6-well culture plates and cultured for $24 \mathrm{~h}$ in antibioticfree growth medium. Prior to infection, the bacteria were centrifuged for $3 \mathrm{~min}$ at $2,500 \mathrm{x} \mathrm{g}$, resuspended and adjusted to $6 \times 10^{8} \mathrm{CFU} / \mathrm{ml}$ in antibiotic-free MEM. The bacterials were added to the epithelial cells at a multiplicity of infection (MOI, ratio of the number of bacteria to the number of epithelial cells) of 10 , after which the infected cells were incubated in a $5 \% \mathrm{CO}_{2}$ incubator for various durations at $37^{\circ} \mathrm{C}$ in antibioticfree growth medium.

Isolation and extraction of capsular polysaccharide (CPS). The CPS was prepared from plate-grown cells as previously described by Enos-Berlage and McCarter (29). V. vulnificus was used to inoculate an LBS plate by being streaked onto the plate and incubated for $24 \mathrm{~h}$ at $30^{\circ} \mathrm{C}$. V. vulnificus was scraped and suspended in $5 \mathrm{ml}$ PBS per plate. Samples were vortexed for $3 \mathrm{~min}$ and shaken at $200 \mathrm{rpm}$ for $2 \mathrm{~h}$ at $30^{\circ} \mathrm{C}$; this process was twice repeated. $V$. vulnificus and debris were removed by centrifugation at $10,000 \mathrm{x}$ g for $20 \mathrm{~min}$. Samples being prepared for monosaccharide analysis were ultracentrifuged at $154,000 \mathrm{x} \mathrm{g}$ for $16 \mathrm{~h}$, and the supernatant containing CPS was collected. The supernatant was then incubated for $8 \mathrm{~h}$ at $37^{\circ} \mathrm{C}$ with $50 \mu \mathrm{g} / \mathrm{ml} \mathrm{RNase} \mathrm{A} \mathrm{(Sigma),} 50 \mu \mathrm{g} / \mathrm{ml}$ DNase I (Sigma) and $10 \mathrm{mM} \mathrm{MgCl}$, followed by further incubation with $200 \mu \mathrm{g} / \mathrm{ml}$ proteinase $\mathrm{K}$ (Sigma) for $16 \mathrm{~h}$ at $37^{\circ} \mathrm{C}$. The sample was extracted twice with phenol-chloroform, precipitated with 2.5 volumes of ethanol, washed with $70 \%$ ethanol and suspended in distilled water. In order to remove the trace amount of endotoxin (LPS) in the CPS fraction, the fraction was eluted through a Detoxi-Gel endotoxin-removing column (Pierce Biotechnology, Rockford, IL, USA) more than two times. The CPS levels were quantitated according to the method of Reddy et al (18). The concentration of the LPS in the purified CPS fraction was $<0.05$ endotoxin units in $10 \mu \mathrm{g} /$ $\mathrm{ml}$ of CPS, as determined using the Limulus Amebocyte 
Lysate QCL-1000 Kit (BioWhittaker, Walkersville, MD, USA).

Treatment with CPS. INT-407 cells were incubated for $24 \mathrm{~h}$ with $50 \mu \mathrm{g} / \mathrm{ml}$ of the $V$. vulnificus CPS (Vv-CPS) or proteinase $\mathrm{K}(1 \mathrm{mg} / \mathrm{ml})$-treated $\mathrm{Vv}-\mathrm{CPS}$ at $37^{\circ} \mathrm{C}$ in $5 \% \mathrm{CO}_{2}$, after which the culture supernatants were analyzed for IL-8 protein levels via an ELISA. For determination of mRNA expression, INT-407 cells were treated for $1 \mathrm{~h}$, and mRNA expression for cytokines, TLR2 and B-actin were determined by RT-PCR. Some of the INT-407 cells were pre-incubated for $1 \mathrm{~h}$ with $5 \mu \mathrm{g} / \mathrm{ml}$ rabbit anti-TLR2 $\mathrm{mAb}$, isotype IgG antibody or medium alone, followed by washing with PBS. INT-407 cells were then treated for $24 \mathrm{~h}$ with purified Vv-CPS at $10-100 \mu \mathrm{g} / \mathrm{ml}$ (IL-8 levels by an ELISA) or for 30-90 min with Vv-CPS (NF-kB binding by an EMSA).

Transient transfection and luciferase reporter assay. INT-407 cells were transiently transfected with human IL- 8 gene

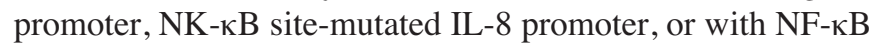
minimal promoter constructs as previously described (14). In brief, the INT-407 cells were plated at a density of $2 \times 10^{4}$ cells/ well in 24-well culture plates. After $24 \mathrm{~h}$ of culture, INT-407 cells were transiently transfected with each of the human IL-8 promoter constructs and with NF- $\mathrm{\kappa B}$ minimal promoter by using the Superfect method (Qiagen, Valencia, CA, USA) according to the manufacturer's instructions. The transfected cells were incubated for $12 \mathrm{~h}$ at $37^{\circ} \mathrm{C}$ in a $5 \% \mathrm{CO}_{2}$ incubator, followed by infection with $V$. vulnificus for $1 \mathrm{~h}$ in antibioticfree MEM medium at an MOI of 10 . The cells were washed in PBS, after which the cells were incubated for $18 \mathrm{~h}$ in the presence of gentamicin $(100 \mu \mathrm{g} / \mathrm{ml})$. Afterwards, the cells were harvested and suspended for $20 \mathrm{~min}$ in $50 \mu 1$ of lysis buffer. The supernatant fluid was harvested and assayed for luciferase activity using Luciferase Reagent (Promega) in a Luminometer. The results were normalized to $L a c Z$ expression and were expressed as relative fold induction.

$R T-P C R$. Total RNA was prepared from the cells and reversetranscribed into cDNA, after which the cDNA was amplified by PCR. Total RNA was purified from the INT-407, HEK293/Null, HEK293/hTLR2/CD14, or HEK293/hTLR4/ MD-2/CD14 cells stimulated with $V$. vulnificus, Vv-CPS (10$100 \mu \mathrm{g} / \mathrm{ml})$, LTA $(10 \mu \mathrm{g} / \mathrm{ml})$ (Sigma, L3265) or E. coli LPS (100 $\mathrm{ng} / \mathrm{ml}$ or $2 \mu \mathrm{g} / \mathrm{ml}$ ) (Sigma, L4391). cDNA was synthesized from $1 \mu \mathrm{g}$ of total RNA by using AccuPower ${ }^{\circledR}$ RT Premix (Bioneer Co., Korea). The PCR was performed on reaction mixtures $(20 \mu \mathrm{l})$ containing $\sim 2 \mu \mathrm{l}(2 \mu \mathrm{l}$ of a 1:5 dilution for $\beta$-actin) of cDNA by using AccuPower ${ }^{\circledR}$ PCR Premix (Bioneer Co.). The primers used were as follows: human IL-8 (302 bp; 36 cycles), 5'-ATGACTTCCAAG CTGGCCGTGGCT-3' (sense) and 5'-TTATGAATTCTCA GCCCTCTTCAAAAACTTCTC-3' (antisense); human TLR2 (263 bp; 36 cycles), 5'-TGAGAGTGGGAAATATG GAC-3' (sense) and 5'-ATGGAAAGTGTCCAAATCAG-3' (antisense); $\beta$-actin (373 bp; 27 cycles), 5'-TTCTACAATGA GCTGCGTGTGGCT-3' (sense) and 5'-GCTTCTCCTTAAT GTCACGCACGA-3' (antisense). Reactions were conducted in an MJ Thermal Cycler (MJ Research, Watertown, MA, USA) under the following conditions: denaturation at $94^{\circ} \mathrm{C}$ for $30 \mathrm{sec}$, annealing at $60^{\circ} \mathrm{C}$ for $30 \mathrm{sec}$ and extention at $72^{\circ} \mathrm{C}$ for $30 \mathrm{sec}$. After amplification, the RT-PCR products were separated on $2 \%(\mathrm{w} / \mathrm{v})$ agarose gels and stained with ethidium bromide.

Preparation of cell lysates and Western blot analysis. Cell lysates from INT-407 cells were prepared as previously described (14). The cells were lysed in lysis buffer $(50 \mathrm{mM}$ Tris buffer, $\mathrm{pH} 7.5$, containing $100 \mathrm{mM} \mathrm{NaCl}, 1 \%$ Nonidet P-40, 10\% glycerol, 1 mM EDTA, $1 \mathrm{mM} \mathrm{NaF}, 1 \mathrm{mM}$ sodium orthovanadate, $50 \mu \mathrm{g} / \mathrm{ml}$ each of leupeptin, aprotinin and PMSF) by incubation on ice for $30 \mathrm{~min}$. Lysates were then centrifuged at $13,000 \times \mathrm{g}$ at $4^{\circ} \mathrm{C}$ for $10 \mathrm{~min}$, and the supernatants were transferred to fresh tubes and stored at $-70^{\circ} \mathrm{C}$ until required. Protein concentrations of the lysates were determined by using the $\mathrm{BCA}^{\mathrm{TM}}$ Protein Assay Reagent A (Pierce, USA). Equal amounts $(20 \mu \mathrm{g} / \mathrm{ml})$ of whole cell lysates were subjected to sodium dodecyl sulfate- $7 \%$ polyacrylamide gel electrophoresis (SDS-PAGE). The proteins were transferred onto a polyvinylidene fluoride membrane using a Semi-Phor (Hoefer Scientific Instrument). The membrane was then incubated with washing buffer (PBS solution containing $0.1 \%$ Tween-20) containing $1 \%$ bovine serum albumin for at least $1 \mathrm{~h}$ to block non-specific protein binding. Afterwards, the membrane was, respectively, treated with rabbit antiTLR2 and anti- $\beta$-actin antibodies (Santa Cruz Biotechnology, Inc.). After incubation with HRP-conjugated anti-rabbit antibody, immunoreactive proteins were detected with the ECL System (Amersham Biosciences, UK).

IL-8 ELISA. INT-407 cells were cultured for $24 \mathrm{~h}$ in $60-\mathrm{mm}$ culture dishes prior to infection or stimulated with $V$. vulnificus, Vv-CPS $(10-100 \mu \mathrm{g} / \mathrm{ml})$ or proteinase $\mathrm{K}(100 \mu \mathrm{g} / \mathrm{ml})$-treated Vv-CPS. In some experiments, the intestinal epithelial cells were pretreated for $1 \mathrm{~h}$ with rabbit anti-TLR2 antibody $(10 \mu \mathrm{g} /$ $\mathrm{ml})$ or isotype control $\mathrm{IgG}$ antibody $(10 \mu \mathrm{g} / \mathrm{ml})$ before $V$. vulnificus infection at an MOI of 10 . Afterwards, the cells were washed in PBS and post-cultured for $18 \mathrm{~h}$ in MEM medium containing gentamicin $(100 \mu \mathrm{g} / \mathrm{ml})$. The culture supernatants were then analyzed for the levels of IL-8 protein using the OptEIA ${ }^{\mathrm{TM}}$ Human IL-8 ELISA Kit 2 (BD Pharmingen, San Diego, CA, USA) according to the manufacturer's instructions. The absorbance at $490 \mathrm{~nm}$ of each well in 96-well plates was determined using an ELISA reader.

Preparation of nuclear extracts and electrophoretic mobility shift assay (EMSA). INT-407 cells $\left(8 \times 10^{5} / \mathrm{dish}\right)$ were seeded onto $60-\mathrm{mm}$ culture dishes and cultured for $24 \mathrm{~h}$ in antibiotic-free growth medium and then infected for $1 \mathrm{~h}$ with $V$. vulnificus at an MOI of 10, or stimulated with $\mathrm{Vv}_{\mathrm{V}} \mathrm{CPS}$ $(50 \mu \mathrm{g} / \mathrm{ml})$. The nuclear extracts from the INT-407 cells were prepared as previously described (14). In brief, the infected cells were washed twice in PBS and resuspended in hypotonic buffer (10 mM HEPES buffer, $\mathrm{pH} 7.9$, containing $0.5 \mathrm{mM} \mathrm{KCl}, 1.5 \mathrm{mM} \mathrm{MgCl}, 0.5 \mathrm{mM}$ DTT and $0.2 \mathrm{mM}$ PMSF). After the cells were allowed to swell on ice for $10 \mathrm{~min}$, a $10 \%$ solution of Nonidet P-40 was added, and the cells were maintained for $15 \mathrm{~min}$ on ice. The homogenates were centrifuged for $15 \mathrm{~min}$ at $4,000 \mathrm{rpm}$, and the resultant nuclear 
A

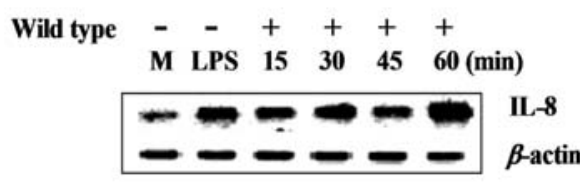

B

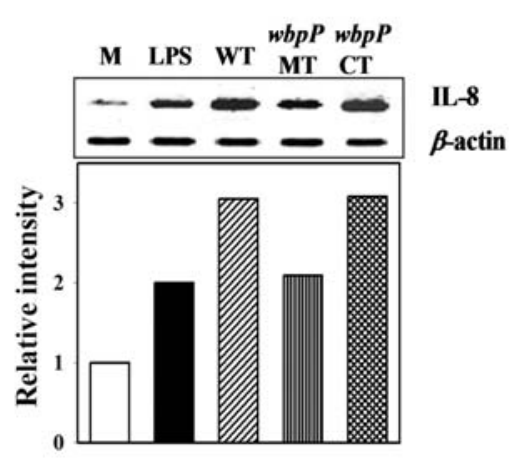

D

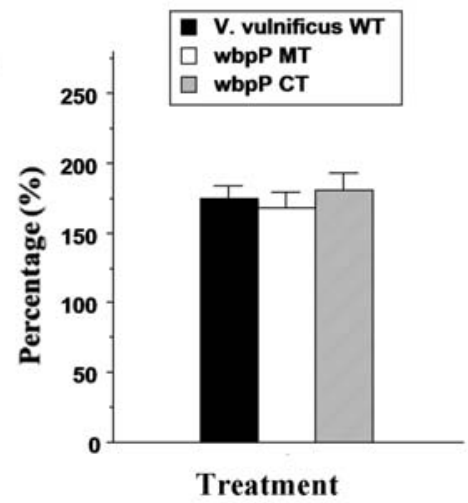

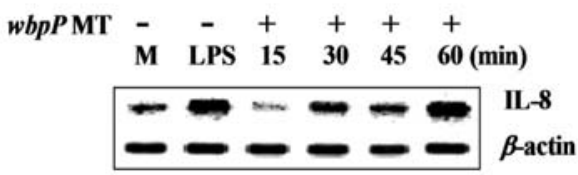

C

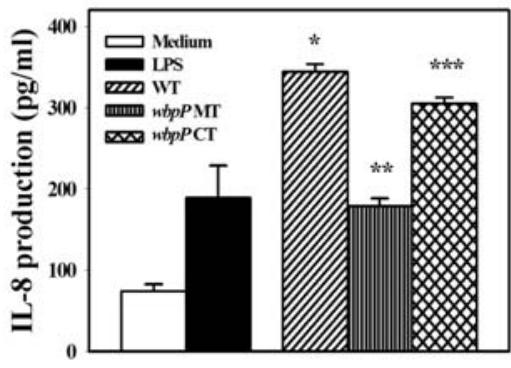

Treatment

$\mathbf{E}$

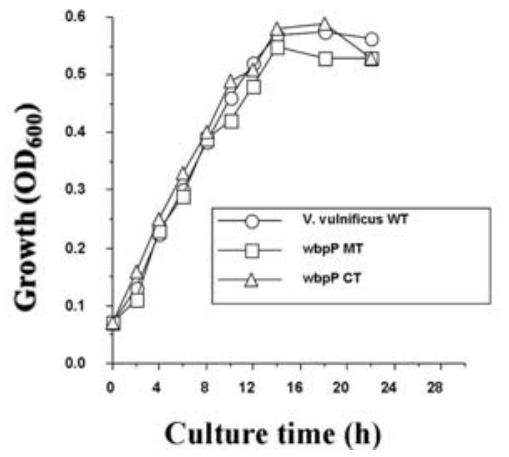

Figure 1. The $w b p P$ mutant $V$. vulnificus induces significantly lower levels of IL-8 production from INT-407 cells in comparison to the wild-type. (A) INT-407 cells were infected for 15-60 min with $V$. vulnificus wild-type (WT) or wbpP mutant-type (wbpP MT) at an MOI of 10. As controls, some cells were incubated with $10 \mu \mathrm{g} / \mathrm{ml}$ of LPS or medium (M) alone. (B) INT-407 cells were infected for 60 min with WT, wbpP MT or $w b p P$ complemented-type ( $w b p P$ CT) at an MOI of 10. Cellular RNA was extracted, and IL-8 mRNA expression was determined by RT-PCR. The results were normalized to 3 -actin expression. The intensity of each band was densitometrically determined and expressed as the relative intensity to the corresponding controls treated with medium alone. (C) INT-407 cells were infected for $1 \mathrm{~h}$ with WT, wbpP MT or wbpP CT at an MOI of 10, followed by washing with PBS and $18 \mathrm{~h}$ of postincubation in the growth medium in the presence of gentamicin $(100 \mu \mathrm{g} / \mathrm{ml})$. As controls, some cells were stimulated with LPS $(100 \mathrm{ng} / \mathrm{ml})$ or medium alone. The IL- 8 protein levels of the culture supernatants were analyzed by ELISA. Data are expressed as the means \pm SE ( $n=3$ ). * $<<0.001$, relative to the group with the medium alone. ${ }^{* *} \mathrm{p}<0.001$, relative to the group infected with the WT. ${ }^{* * *} \mathrm{p}<0.01$, relative to the group infected with the $w b p P$ MT. Data are representative of three independent experiments. (D) INT-407 cells were infected for $1 \mathrm{~h}$ with WT, $w b p P$ MT or $w b p P$ CT at an MOI of 10 , after which the total CFU numbers were determined. Data are presented as the percentages of the inocular and are the means \pm SE for three independent experiments with triplicate samples. (E) V.vulnificus WT, wbpP MT and wbpP CT $\left(5 \times 10^{6} \mathrm{CFU}\right)$ were cultured in multiple-well plates, and the growth of each strain was measured by spectrometric measurement at $\mathrm{OD}_{600}$. Data represent the means of three independent experiments.

pellets were resuspended in $50 \mu 1$ of low salt buffer $(20 \mathrm{mM}$ HEPES buffer, pH 7.9, containing 25\% glycerol, $1.5 \mathrm{mM}$ $\mathrm{MgCl}_{2}$ and $0.2 \mathrm{mM}$ PMSF) and then $50 \mu \mathrm{l}$ of high salt buffer (20 mM HEPES buffer, pH 7.9, containing 25\% glycerol, $1.5 \mathrm{mM} \mathrm{MgCl}_{2}, 0.8 \mathrm{M} \mathrm{KCl}, 0.2 \mathrm{mM}$ EDTA, $0.5 \mathrm{mM}$ DTT and $0.2 \mathrm{mM}$ PMSF) in a dropwise fashion. The nuclear extract was centrifuged for $30 \mathrm{~min}$ at $20,500 \mathrm{x} \mathrm{g}$ at $4^{\circ} \mathrm{C}$. Ten micrograms of each of the nuclear extracts was incubated for $30 \mathrm{~min}$ with the labeled oligonucleotides in $20 \mu 1$ of binding buffer (10 mM Tris- $\mathrm{HCl}, \mathrm{pH} 7.6,500 \mathrm{mM} \mathrm{KCl}, 10 \mathrm{mM}$ EDTA, $50 \%$ glycerol, $250 \mathrm{ng}$ of poly $(\mathrm{dI}-\mathrm{dC})$ and $1 \mathrm{mM}$ dithiothreitol). The reaction mixture was analyzed by electrophoresis on a $4 \%$ polyacrylamide gel in $0.5 \mathrm{X}$ Tris borate buffer. An oligonucleotide harboring an NF-кB binding site (5'-CCGGTTAACAGAGGGGGCTTTCCGAG-3') was used as a probe. Specific binding was verified via competition experiments with a 50-fold excess of unlabeled identical oligonucleotides of cAMP response element (CRE)containing oligonucleotides.

Statistical analyses. Student's t-tests and one-way analysis of variance (ANOVA) followed by the Bonferroni method, were employed in order to determine statistical differences between the values of the various experimental and control groups. P-values $<0.05$ were considered to be statistically significant. 


\section{Results}

The capsular polysaccharide-defective mutant of $V$. vulnificus induces significantly lower levels of IL-8 production in human intestinal epithelial cells than the wild-type. In order to evaluate the role of $V$. vulnificus CPS in the induction of IL-8 expression from human intestinal epithelial cells, INT-407 cells were infected with either the $w b p P$ mutant or with the wild-type $V$. vulnificus as a control, and the levels of IL-8 expression were determined. As shown in Fig. 1A, the levels of IL-8 mRNA were lower in INT-407 cells infected with the $w b p P$ mutant, as compared with those infected with the wildtype strain. Importantly, the reduced IL- 8 mRNA levels were restored in INT-407 cells infected with the $w b p P$-complemented $V$. vulnificus (Fig. 1B). The CPS production of wbpPcomplemented $V$. vulnificus was found to be restored to a level comparable to the level of wild-type $V$. vulnificus (22).

Additionally, infection with the $w b p P$ mutant induced significantly lower levels of IL-8 production in INT-407 cells than did the wild-type strain. As shown in Fig. 1C, infection with wild-type $V$. vulnificus profoundly induced IL-8 production by INT-407 cells; the levels induced were higher than those induced by LPS treatment. INT-407 cells exposed to the $w b p P$ mutant secreted $178.29 \pm 10.07 \mathrm{pg} / \mathrm{ml}$ of IL-8 for $18 \mathrm{~h}$, which was significantly lower than the levels $(343.6 \pm 9.62 \mathrm{pg} / \mathrm{ml})$ secreted by the wild type-infected INT-407 cells. In addition, the reduction in IL- 8 production affected by the $w b p P$ mutant did not appear to result from a general inhibitory effect on epithelial cell proliferation, as the cell number and viability of all cultures remained approximately constant throughout the incubation period in the presence of $V$. vulnificus, as demonstrated by the results of a trypan blue exclusion assay. Importantly, the decreased levels of IL-8 production were also restored as a result of $w b p P$ gene complementation into the $w b p P$ mutant $V$. vulnificus $(304.46 \pm 7.69 \mathrm{pg} / \mathrm{ml})$ (Fig. 1C). The growth rates of the three $V$. vulnificus strains (WT, MT and CT) did not differ significantly (Fig. 1D), and the CFU values of $V$. vulnificus at the time of the assay were approximately identical in the culture supernatants of INT-407 cells incubated with $V$. vulnificus WT, MT and CT, respectively (Fig. 1E). These results indicate that the reduction in IL- 8 induction mediated by the capsular polysaccharide-defective $w b p P$ mutant, as compared to what was observed with the wild-type, occurred at the mRNA and protein levels.

The capsular polysaccharide-defective wbpP mutant $V$. vulnificus induces lower levels of $N F-\kappa B$ activity. NF- $\kappa \mathrm{B}$, NF-IL-6, and AP-1 are three transcriptional factors that are crucial for the regulation of IL-8 gene expression $(30,31)$. We previously determined that the NF- $\mathrm{KB}$ site performed an important function in IL-8 gene expression occurring after $V$. vulnificus infection (14). In order to test directly the role of a NF- $\mathrm{KB}$ site found between -80 and -71 of the IL- 8 full promoter on the stimulatory effect induced by $V$. vulnificus CPS, we introduced a linker scanning mutation into the $\mathrm{NF}-\kappa \mathrm{B}$ site within the context of the $-144 /+44$ construct IL-8/LS promoter (Fig. 2A). In order to determine whether the $w b p P$ mutation also affected the activity of the IL- 8 gene promoter, the INT-407 cells were transfected with the IL-8
A

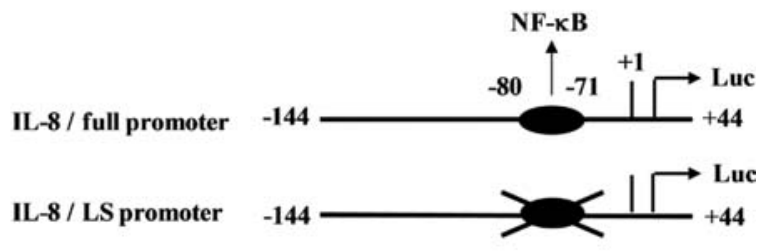

B

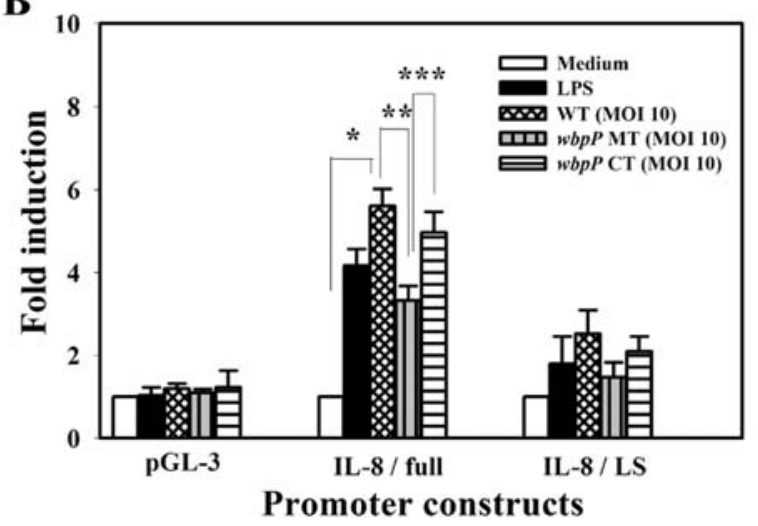

Figure 2. The levels of IL-8 gene promoter activity are significantly lower in INT-407 cells infected with the $w b p P$ mutant than those infected with the wild type $V$. vulnificus. (A) A schematic representation of the human IL-8/ full or IL-8/LS promoter constructs. (B) INT-407 cells were transiently transfected with the empty vector, IL-8 full promoter or NF- $\mathrm{BB}$ site-mutated IL-8 promoter (IL-8/LS promoter) construct, followed by $1 \mathrm{~h}$ of infection with WT, $w b p P$ MT or $w b p P$ CT at an MOI of 10. As controls, some cells were stimulated with $100 \mathrm{ng} / \mathrm{ml}$ LPS or medium alone. Afterwards, the cells were post-cultured for $18 \mathrm{~h}$ in the presence of gentamicin $(100 \mu \mathrm{g} / \mathrm{ml})$, and the luciferase activity was determined. The results were normalized to LacZ expression. The results are expressed as the induction fold over the value obtained with the uninfected INT-407 cells transfected with the IL-8 minimal promoter construct, which was assigned an arbitrary value of 1 . Data are expressed as the means $\pm \mathrm{SE}(\mathrm{n}=3)$. ${ }^{*} \mathrm{p}<0.005$, relative to the group with medium alone. ${ }^{* *} \mathrm{p}<0.05$, relative to the group infected with the WT ${ }^{* * *} \mathrm{p}<0.05$, relative to the group infected with the $w b p P \mathrm{MT}$.

full promoter/luciferase construct and were subsequently infected with the $w b p P$ mutant, wild-type, or $w b p P$ complemented $V$. vulnificus, after which the luciferase activity was assessed. As indicated (Fig. 2B), the IL-8 promoter construct evidenced significant stimulation with $V$. vulnificus infection. However, IL-8 promoter activity was found to be significantly lower in the INT-407 cells infected with the wbpP mutant than in those infected with the wild-type. In addition, the IL- 8 promoter activity was also restored in the INT-407 cells infected with the $w b p P$-complemented $V$. vulnificus. Furthermore, the $V$. vulnificus CPS-dependent promoter activation was still observed with the IL-8/LS promoter, although it was significantly reduced in comparison with the IL-8/full promoter. However, the reduced effect of the $w b p P$ mutant on IL- 8 promoter activation was not observed in the IL-8/LS promoter as compared to the IL-8/ full promoter. This result clearly indicates that the stimulatory effect of $V$. vulnificus CPS on IL-8 production may be mediated through the $\kappa \mathrm{B}$ site.

In an effort to determine whether or not NF- $\mathrm{B}$ activity was involved in the reduced levels of IL-8 production in human intestinal epithelial cells infected with the CPS- 
$\mathbf{A}$

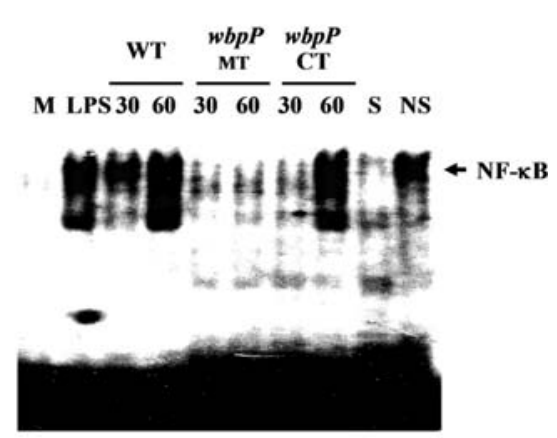

B

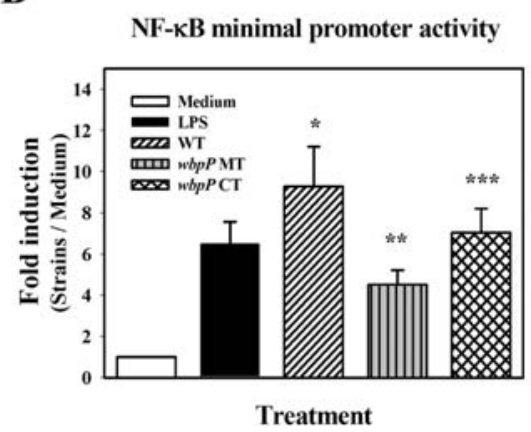

Figure 3. The $w b p P$ mutant induces lower levels of NF-кB activation in INT-407 cells than the wild-type. (A) INT-407 cells were infected for 30 or 60 min with the WT, $w b p P$ MT or $w b p P$ CT at an MOI of 10 . The nuclear extracts were examined for NF- $\mathrm{B}$ DNA binding activity via an electrophoretic mobility shift assay. As controls, some cells were stimulated with LPS or with medium alone. S and NS indicate the presence of a 50-fold excess of specific oligonucleotide (NF- $\mathrm{B}$ ) and non-specific oligonucleotide (CRE), respectively. (B) INT-407 cells were transiently transfected with the NF-кB minimal promoter construct, followed by $1 \mathrm{~h}$ of infection with the wild-type, $w b p P$ MT or $w b p P$ CT at an MOI of 10. Afterwards, the cells were post-cultured for $18 \mathrm{~h}$ in the presence of gentamicin $(100 \mu \mathrm{g} / \mathrm{ml})$, and the luciferase activity was assessed. The results were normalized to $L a c Z$ expression. The results are expressed as the induction fold over the value obtained with the uninfected INT-407 cells transfected with the NF-кB minimal promoter construct, which was assigned as an arbitrary value of 1 . Data represent the means $\pm \operatorname{SE}(n=3) .{ }^{*} \mathrm{p}<0.05$, relative to the group incubated with medium alone. ${ }^{* *} \mathrm{p}<0.01$, relative to the group infected with the WT. ${ }^{* * *} \mathrm{p}<0.05$, relative to the group infected with the $w b p P$ MT.

defective $w b p P$ mutant, we evaluated NF-кB DNA binding activity in the nuclear extract of the wild-type-, $w b p P$ mutant-, or wbpP-complemented $V$. vulnificus-infected INT-407 cells. As shown in Fig. 3A, the wild-type-infected intestinal epithelial cells exhibited strong NF-кB binding activity, whereas the $w b p P$ mutant induced significantly lower levels of NF- $\kappa \mathrm{B}$ DNA binding activity compared to the wild-type based on the results of electrophoretic mobility shift assays using a labeled oligonucleotide harboring a consensus NF-KB site. This binding was determined to be specific as it competed with an unlabeled identical oligonucleotide, but not with an unrelated non-specific oligonucleotide, and was detected in the nuclear extracts from the wild type-infected cells. Furthermore, the reduced levels of $\mathrm{NF}_{-} \mathrm{\kappa B}$ DNA binding activity in the wbpP mutant-infected cells were also restored by the complementation of the $w b p P$ gene into the mutant (Fig. 3A).

To further assess whether NF- $\mathrm{KB}$ activity played a role in the reduced levels of IL-8 production in human epithelial cells infected with the CPS-defective wbpP mutant, INT-407 cells were transiently transfected with the NF-кB minimal promoter/luciferase construct followed by $V$. vulnificus infection, and the luciferase activity was determined. As shown in Fig. 3B, the NF- $\mathrm{BB}$ minimal promoter construct exhibited potent stimulation with the wild-type. However, the levels of NF-кB transactivation were significantly reduced in INT-407 cells infected with the $w b p P$ mutant $V$. vulnficus. Additionally, the reduced NF- $\kappa \mathrm{B}$ minimal promoter activity induced by the CPS-defective $w b p P$ mutant was partially restored by the $w b p P$-complemented $V$. vulnificus (Fig. 3B). These results clearly show that the $V$. vulnificus capsular polysaccharide is involved in the production of IL-8 from human intestinal epithelial cells which is closely correlated with $\mathrm{NF}-\kappa \mathrm{B}$ activation.

The capsular polysaccharide-defective wbpP mutant $V$. vulnificus induces lower levels of TLR2 expression. In order to determine whether the CPS-defective wbpP mutant affects the expression of TLRs, INT-407 cells were infected with the wild-type or the $w b p P$ mutant strain, and the mRNA expression of TLRs was determined by RT-PCR. As shown in Fig. 4A and B, INT-407 cells expressed low levels of TLRs including TLR2, which was significantly increased upon infection with the wild-type $V$. vulnificus in a timedependent manner. In contrast, the expression of the TLR2 molecule in INT-407 cells was not responsive to the $w b p P$ mutant of $V$. vulnificus, whereas the expression of the other TLRs was increased by the $w b p P$ mutant, to a degree similar to that of the wild-type (data not shown), thereby indicating that the $w b p P$ gene may be specifically involved in the upregulation of TLR2 expression in response to infection with $V$. vulnificus. Additionally, the $w b p P$ mutant induced lower levels of the TLR2 protein than did the wild-type $V$. vulnificus (Fig. 4C). Importantly, the reduced TLR2 mRNA and protein levels were restored via the complementation of the $w b p P$ gene into the $w b p P$ mutant $V$. vulnificus (Fig. 4B and C). These data demonstrate that the $V$. vulnificus capsular polysaccharide induces IL- 8 production in human intestinal epithelial cells via a TLR2-dependent signaling pathway.

The V. vulnificus capsular polysaccharide is involved in the induction of IL-8 production via a TLR2/NF- $\kappa B$-dependent pathway. In order to further assess the role of defective TLR2 signaling in the down-regulation of IL-8 production as the result of reduced NF- $\mathrm{NB}$ activation mediated by the CPSdefective $w b p P$ mutant, INT-407 cells were incubated with anti-TLR2 antibody followed by infection with $V$. vulnificus, and the levels of NF-kB minimal promoter activity and IL-8 production were analyzed via a luciferase reporter assay and ELISA, respectively. As shown in Fig. 5A and B, pretreatment of the intestinal epithelial cells with anti-TLR2 antibody resulted in a significant reduction in NF- $\mathrm{KB}$ minimal promoter activity and IL- 8 production in the INT-407 cells infected with the wild-type or the wbpP-complemented V. vulnificus. AntiTLR2 $\mathrm{mAb}$ treatment also caused a reduction in the activity of the NF- $\mathrm{KB}$ minimal promoter activity and IL- 8 production levels in the $w b p P$ mutant-infected INT-407 cells, but to a significantly lower degree than the levels observed in the infected cells with either the wild-type or the $w b p P$ complemented types. These data indicate that the $w b p P$ gene 
$\mathbf{A}$
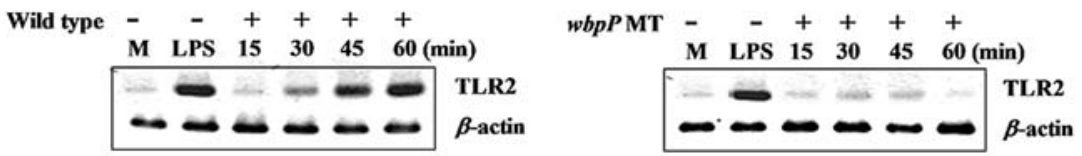

B

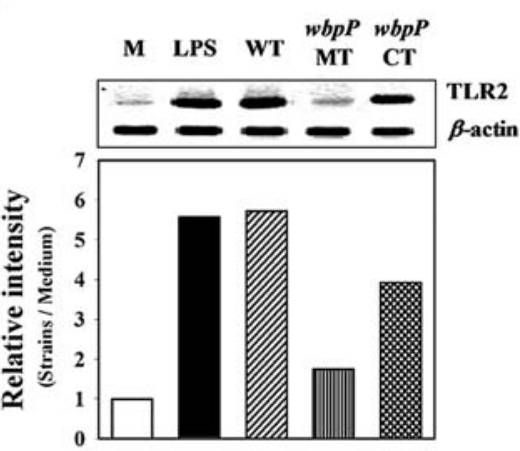

C
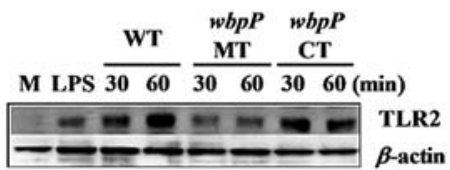

Figure 4. The $w b p P$ mutant induces lower levels of TLR2 gene expression from INT-407 cells than the wild-type. (A) INT-407 cells were infected for 15-60 min with the WT or $w b p P$ mutant at an MOI of 10 . As a control, some cells were stimulated with $10 \mu \mathrm{g} / \mathrm{ml}$ LPS or medium alone. (B) INT-407 cells were infected for 60 min with the WT, $w b p P$ MT or $w b p P$ CT at an MOI of 10. Cellular RNA was extracted, and TLR2 expression was determined by RT-PCR. (C) INT-407 cells were infected for 60 min with the WT, $w b p P$ MT or $w b p P$ CT at an MOI of 10 . The cell lysates were prepared and analyzed by Western blot analysis using anti-TLR2 and B-actin antibody as a control. The results were normalized to B-actin expression. The intensity of each band was densitometrically determined and expressed as the relative intensity to the corresponding controls treated with medium (M). Data are representative of four independent experiments.

of V. vulnificus is involved in TLR2-dependent IL-8 production via the $V$. vulnificus infection-mediated alteration of NF-кB activation, and that the deficiency of CPS caused by the $w b p P$ gene mutation of $V$. vulnificus resulted in a reduction in IL-8 production of human intestinal epithelial cells.

\section{A}

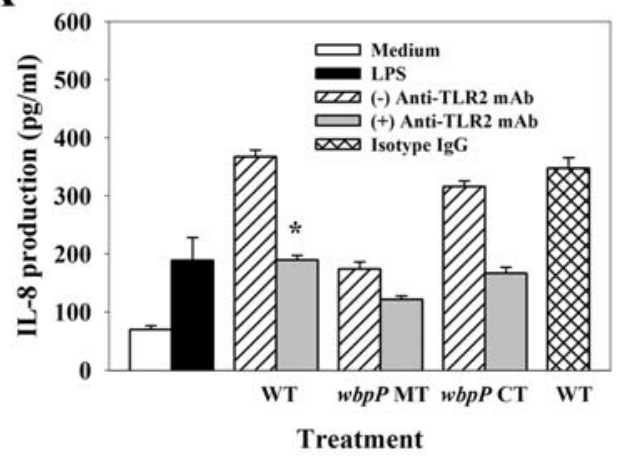

\section{B NF- $\kappa$ B minimal promoter activity}

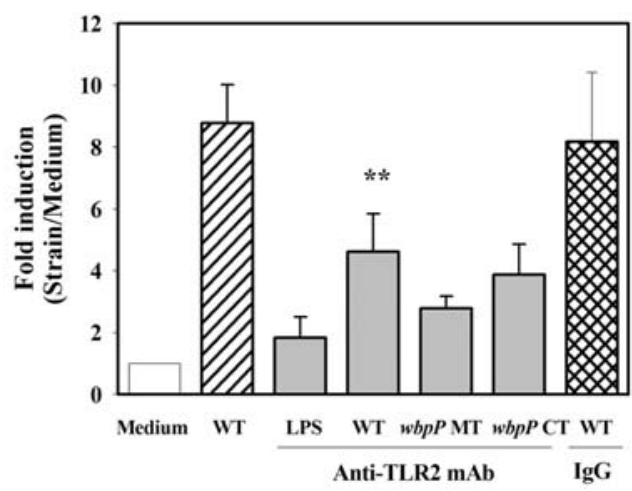

Purified capsular polysaccharide of $V$. vulnificus induces $I L-8$ production through a TLR2-dependent $N F-\kappa B$ activation pathway. Finally, we attempted to ascertain whether or not the purified $V$. vulnificus CPS ( $V_{v-C P S}$ ) could induce IL-8 production via TLR2-dependent NF- $\mathrm{KB}$ activation. In order to remove the trace amount of endotoxin (LPS) in the CPS fraction, the fraction was eluted through a Detoxi-Gel endotoxin-removing column at least two times. The LPS concentration in the purified CPS fraction was $<0.05$ endotoxin units in $10 \mu \mathrm{g} / \mathrm{ml}$ of CPS. INT-407 cells were treated with the purified CPS, and the expression levels of the cytokine genes and NF-кB DNA binding activity were determined. As

Figure 5. Involvement of TLR2 signaling in the induction of IL-8 production by a capsular component of $V$. vulnificus in human intestinal epithelial cells. (A) INT-407 cells were pre-incubated for $1 \mathrm{~h}$ with the anti-TLR2 $\mathrm{mAb}$ or isotype IgG control antibody at $5 \mu \mathrm{g} / \mathrm{ml}$ followed by $1 \mathrm{~h}$ of infection with the WT, wbpP MT or wbpP CT of $V$. vulnificus at an MOI of 10 . As controls, some cells were stimulated with $100 \mathrm{ng} / \mathrm{ml}$ of LPS or medium alone. Afterwards, the cells were washed with PBS and incubated for an additional $18 \mathrm{~h}$ in the presence of gentamicin $(100 \mu \mathrm{g} / \mathrm{ml})$. The culture supernatants were analyzed for IL- 8 protein levels using ELISA. Data are expressed as the means $\pm \mathrm{SE}(\mathrm{n}=3)$. ${ }^{*} \mathrm{p}<0.001$, relative to the group infected with the WT in the absence of anti-TLR2 mAb. (B) INT-407 cells were transiently transfected with the $\mathrm{NF}-\kappa \mathrm{B}$ minimal promoter/luciferase construct followed by incubation for $1 \mathrm{~h}$ with the anti-TLR $2 \mathrm{mAb}$ or isotype IgG control antibody at $5 \mu \mathrm{g} / \mathrm{ml}$ and a subsequent $1 \mathrm{~h}$ of infection with the WT, wbpP MT or wbpP CT of $V$. vulnificus at an MOI of 10. Afterwards, the cells were washed in PBS and then incubated for $18 \mathrm{~h}$ in the presence of gentamicin $(100 \mu \mathrm{g} / \mathrm{ml})$, and the luciferase activity was determined. The results were normalized to $L a c Z$ expression. The results are expressed as the induction fold over the value obtained with the uninfected INT-407 cells transfected with the NF- $\mathrm{B}$ minimal promoter construct, which was assigned as an arbitrary value of 1 . Data are expressed as the means $\pm \operatorname{SE}(n=3)$. ${ }^{* *} \mathrm{p}<0.05$, relative to the group infected with the WT in the absence of the anti-TLR2 $\mathrm{mAb}$. 
A

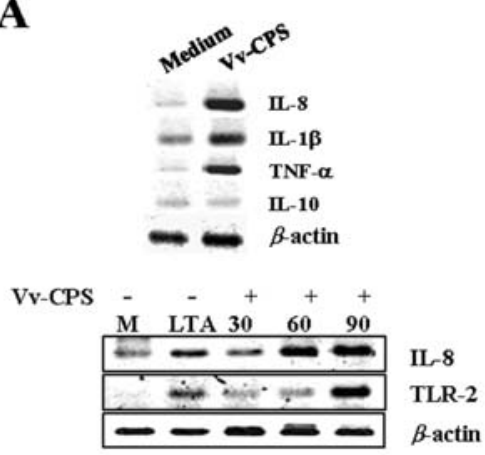

B

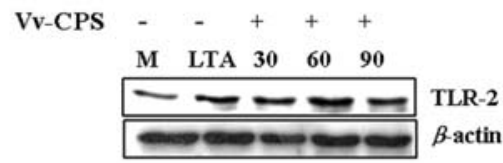

C

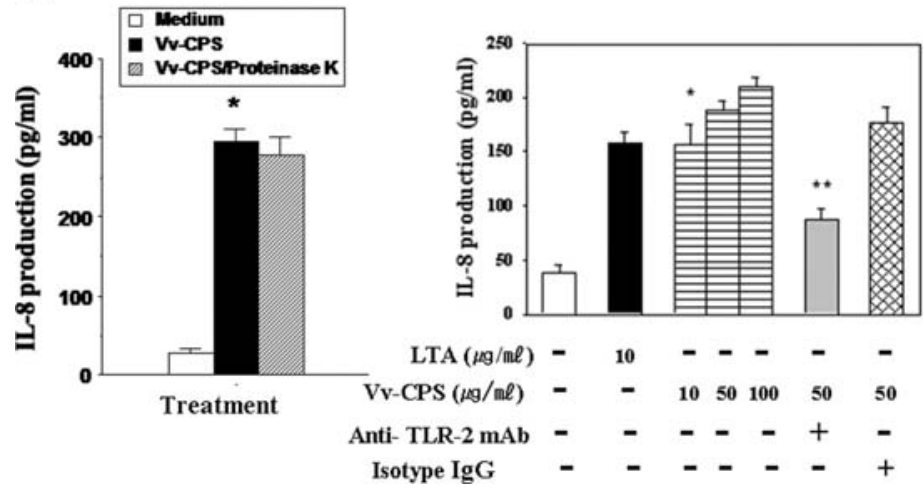

D

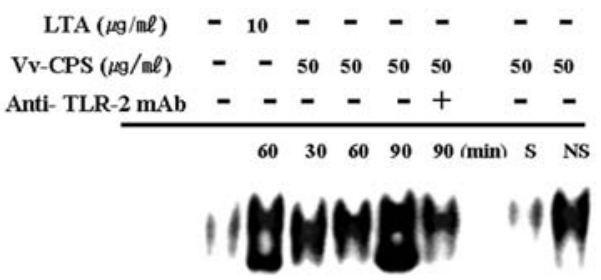

Figure 6. IL-8 production by the purified capsular polysaccharide of $V$. vulnificus involves TLR2-dependent activation of NF-kB in human intestinal epithelial cells. (A) INT-407 cells were treated with the purified $V$. vulnificus CPS (Vv-CPS, $50 \mu \mathrm{g} / \mathrm{ml}$ ). Cellular RNAs were extracted, and the levels of cytokines, TLR2, and B-actin mRNA were determined by RT-PCR. As a control, some cells were stimulated with $10 \mu \mathrm{g} / \mathrm{ml} \mathrm{LTA.} \mathrm{(B)} \mathrm{The} \mathrm{cell} \mathrm{lysates} \mathrm{were} \mathrm{prepared} \mathrm{and}$ analyzed by Western blot analysis using anti-TLR2 and B-actin antibody as a control. Data are representative of two independent experiments. (C) INT-407 cells were incubated for $24 \mathrm{~h}$ with $50 \mu \mathrm{g} / \mathrm{ml}$ of the Vv-CPS or proteinase $\mathrm{K}(100 \mu \mathrm{g} / \mathrm{ml})$-treated Vv-CPS, after which the culture supernatants were analyzed for IL-8 protein levels using ELISA. Some of the INT-407 cells were pre-incubated for $1 \mathrm{~h}$ with $5 \mu \mathrm{g} / \mathrm{ml}$ anti-TLR2 mAb, isotype IgG antibody or medium alone followed by washing with PBS. INT-407 cells were then treated for $24 \mathrm{~h}$ with purified Vv-CPS at 10-100 $\mu \mathrm{g} / \mathrm{ml}$. Data represent the means \pm SE ( $\mathrm{n}=3$ ). ${ }^{*} \mathrm{p}<0.05$, relative to the group incubated with medium alone. ${ }^{* *} \mathrm{p}<0.01$, relative to the group treated with CPS $(50 \mu \mathrm{g} / \mathrm{ml})$ in the absence of anti-TLR2 mAb. (D) INT-407 cells were pre-incubated for $1 \mathrm{~h}$ with $5 \mu \mathrm{g} / \mathrm{ml}$ anti-TLR $2 \mathrm{mAb}$ or medium alone followed by washing with PBS. INT-407 cells were then treated with purified Vv-CPS $(50 \mu \mathrm{g} / \mathrm{ml})$ for 30-90 min. The nuclear extracts were examined for NF-kB DNA binding activity in the electrophoretic mobility shift assay. S and NS indicate the presence of a 50-fold excess of specific oligonucleotide (NF-kB) and non-specific oligonucleotide (CRE), respectively.

shown in Fig. 6, the purified Vv-CPS significantly induced the expression of cytokines such as IL-8, IL-1ß and TNF- $\alpha$, whereas the Vv-CPS did not affect the expression of IL-10. Additionally, Vv-CPS treatment strongly induced TLR2 expression and NF- $\mathrm{KB}$ activation in a time- and dose-dependent manner. Furthermore, Vv-CPS treatment significantly induced IL-8 secretion from the INT-407 cells, which was unchanged upon the addition of proteinase K (Fig. 6C). Importantly, as shown in Fig. 6C, the pretreatment of the intestinal epithelial cells with the anti-TLR2 antibody resulted in a significant reduction in IL-8 production in the CPS-stimulated INT-407 cells. Anti-TLR2 $\mathrm{mAb}$ pretreatment also reduced $\mathrm{NF}-\kappa \mathrm{B}$ activation (Fig. 6D). These data clearly show that the $V$. vulnificus capsular polysaccharide induces TLR2-dependent IL-8 production via the NF- $\mathrm{KB}$ activation pathway in human intestinal epithelial cells.

To further determine whether or not TLR2 specifically responded to the $V$. vulnificus CPS and to ascertain that the enhanced TLR2 expression did not result from LPS contamination in the CPS fraction, stable cell lines expressing either TLR2 or TLR4, HEK293/TLR2/CD14 and HEK293/TLR4/ MD-2/CD14, were treated with Vv-CPS, and the levels of TLR2 and TLR4 mRNA were determined. As shown in Fig. 7, treatment with Vv-CPS or LTA as a known TLR2 ligand increased the expression of TLR2 in the HEK293/TLR2/ CD14 cells, whereas stimulation with $E$. coli LPS did not affect TLR2 expression. However, Vv-CPS stimulation was not shown to affect the levels of TLR4 mRNA in HEK293/ TLR4/MD-2/CD14 cells, while LPS stimulation resulted in a significant increase in the levels of TLR4 mRNA (Fig. 7). These data indicate that TLR2 is the receptor responsible for the $V$. vulnificus CPS-induced immune response, and that the enhanced TLR2 expression induced by Vv-CPS treatment did not result from LPS contamination occurring during the preparation of the $\mathrm{Vv}$-CPS.

\section{Discussion}

Capsular polysaccharides contribute to the virulence of a variety of pathogens, and specific capsular types are frequently associated with infectious disease. V. vulnificus exhibits a great deal of variance in terms of its CPS carbohydrate composition $(16,17)$. An epimerase gene was recently reported to be required for CPS expression, and the $w b p P$ gene encodes for a UDP- $N$-acetyl-D-glucosamine $\mathrm{C}_{4}$ epimerase of $V$. vulnificus (20). We previously reported that the $w b p P$ 
A

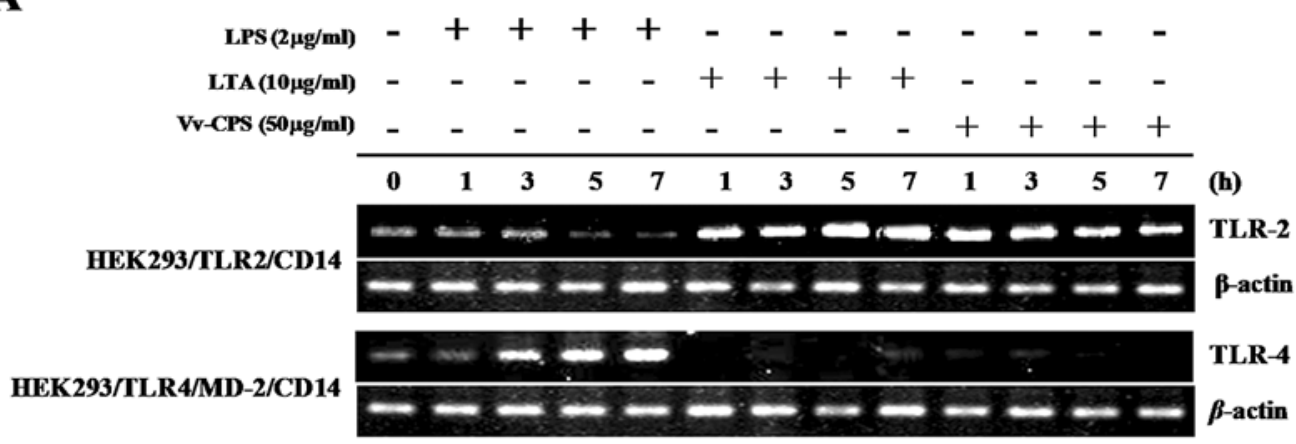

B

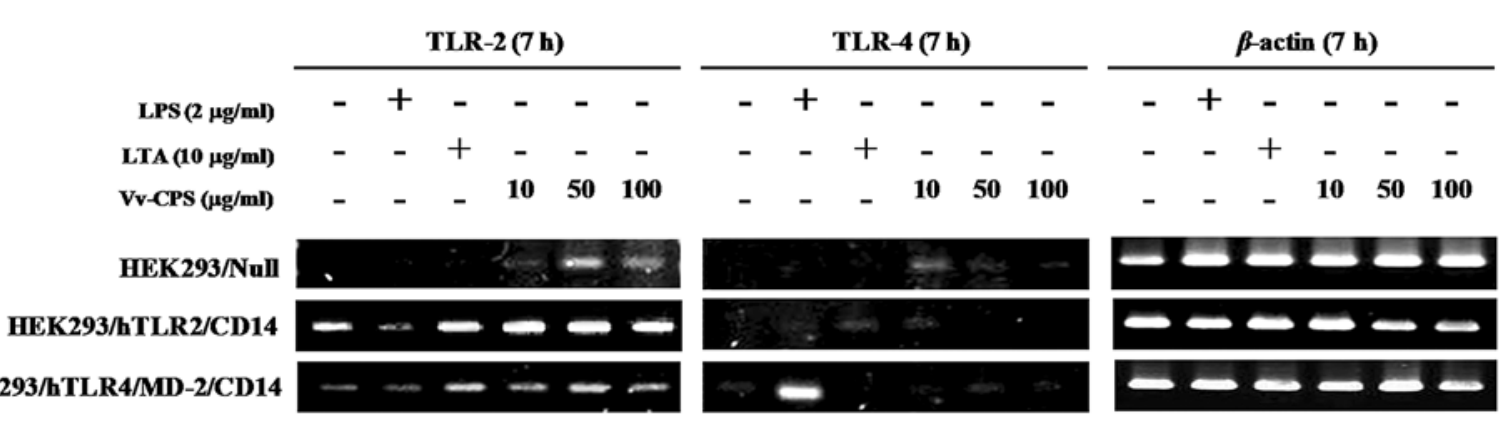

Figure 7. TLR2 mRNA expression is specifically responsive to the purified capsular polysaccharide of $V$. vulnificus. (A) HEK293/TLR2/ CD14 and HEK293/TLR4/MD-2/CD14 cells were incubated for $1-7 \mathrm{~h}$ with $50 \mu \mathrm{g} / \mathrm{ml}$ of Vv-CPS, $2 \mu \mathrm{g} / \mathrm{ml}$ of LPS (E. coli) or $10 \mu \mathrm{g} / \mathrm{ml}$ of LTA. (B) HEK293/ Null, HEK293/TLR2/CD14 and HEK293/TLR4/MD-2/CD14 cells were incubated for $7 \mathrm{~h}$ with 10-50 $\mu \mathrm{g} / \mathrm{ml}$ of Vv-CPS, $2 \mu \mathrm{g} / \mathrm{ml}$ of LPS or 10 $\mu \mathrm{g} / \mathrm{ml}$ of LTA. The levels of TLR2 and TLR4 mRNA were determined by RT-PCR.

mutation of V. vulnificus reduced CPS synthesis and also impaired its ability to attach to epithelial cells in vitro, thereby resulting in an attenuation of virulence in mice (22). In this study, we demonstrated for the first time that the capsular polysaccharide of V. vulnificus induces the IL-8 production in human intestinal epithelial cells. V. vulnificus CPS-mediated IL-8 production may occur via TLR2 signaling and NF- $\mathrm{KB}$ activation. As IL-8 is a chemokine that plays a pivotal role in the mobilization of cellular defense mechanisms and may signal the onset of an acute inflammatory response $(14,23)$, the CPS of $V$. vulnificus may constitute an important mediator of inflammatory response, which contributes to the epithelial injury inherent to $V$. vulnificus infection. Many other studies have reported that the infection of intestinal epithelial cells with pathogenic bacteria including $H$. pylori, S. typhimurium, EPEC or Bacillus subtilis results in increases in IL- 8 production $(32,33)$. In particular, surface polysaccharides such as CPS and lipopolysaccharides, perform crucial functions in the pathogenicity of gram-negative bacteria $(4,5)$.

The mechanism by which the CPS-defective $w b p P$ mutant, as compared to the wild-type of $V$. vulnificus, induced significantly lower levels of IL-8 production at the molecular level remains uncertain. We determined that the CPS-defective $w b p P$ mutant significantly reduced IL-8 production in a timedependent manner (Fig. 1). It also reduced the activation of the IL-8 gene promoter induced by infection with wild-type $V$. vulnificus (Fig. 2), thereby indicating that the reduction in IL-8 production by the CPS-defective $w b p P$ mutant occurred at the transcriptional level. In our study, the CPS-defective
wbpP mutant was also determined to attenuate $\mathrm{NF}-\kappa \mathrm{B}$ promoter activity in response to $V$. vulnificus infection, which was restored by the complementation of the $w b p P$ gene into the wbpP mutant $V$. vulnificus (Fig. 3), thereby indicating that the reduced levels of IL-8 production caused by the $w b p P$ gene mutation in $V$. vulnificus may be mediated via a decrease in NF-кB activation. Furthermore, the infection of INT-407 cells with the wild-type $V$. vulnificus resulted in a marked enhancement of DNA binding activity to the NF- $\mathrm{BB}$ sites, which was significantly reduced by the CPS-defective $w b p P$ mutant (Fig. 3B). The NF-кB transcription factor is known to play a role in the inducible transcription of the IL-8 gene in the activation of mammalian cells, as the promoters of both human and murine IL-8 genes harbor NF- $\mathrm{BB}$ sites $(30,31)$. We recently reported that $V$. vulnificus infection induced the production of IL-8, a proinflammatory cytokine, from human intestinal epithelial cells via NF-кB activation (14).

Additionally, the CPS purified from $V$. vulnificus induced IL-8 production and NF- $\mathrm{BB}$ activation, both of which were suppressed by the addition of anti-TLR $2 \mathrm{mAb}$. This clearly indicates that the CPS was, at least in part, involved in the IL-8 production via the TLR2/NF- $\kappa$ B pathway in the human intestinal epithelial cells. Any possibilities of LPS contamination in the purified CPS fraction could be completely excluded by our direct and indirect experiments, which were designed to demonstrate that there was no contamination of LPS in the purified CPS fraction. The results of the LAL test demonstrated that no detectable amount of LPS existed in the purified CPS fraction. IL-8 production induced by the purified CPS was inhibited by blocking with 
the anti-TLR2 antibody, not by the anti-TLR4 antibody, indicating that the purified CPS fraction did not contain LPS which is involved in IL-8 production as LPS is a well-known TLR4 ligand. In our study, the CPS fraction was repetitively eluted through a Detoxi-Gel endotoxin-removing column at least two times in order to remove any trace amounts of LPS that might have remained in the purified CPS fraction. Furthermore, any possibility of contamination of proteins such as IIpA-encoded protein (34) in the purified CPS fraction was also excluded by the observation that the levels of IL- 8 production induced by the CPS fraction were unaffected prior to and after treatment with proteinase $\mathrm{K}$ or boiling of the fraction.

The TLRs are known to be involved in the induction of IL-8 production. LPS is well known to induce IL-8 production via TLR4 $(35,36)$. Uropathogenic $E$. coli activates IL-8 production via P-fimbriae (37), and the flagellins of different bacteria activate IL-8 via TLR5 $(38,39)$. V. vulnificus FlaB is known to bind directly to human TLR5 expressed on cultured epithelial cells, and consequently induces the activation of NF- $\mathrm{KB}$ and IL-8 production (40). In this study, we demonstrated for the first time that $V$. vulnificus CPS mediates TLR2-dependent IL-8 production in human intestinal epithelial cells. Reduced CPS levels in the $w b p P$ mutant resulted in the reduction of TLR2-dependent IL- 8 production in human intestinal epithelial cells. The CPS-defective $w b p P$ mutant reduced the expression levels of TLR2 and TLR signaling molecules, and these levels were restored by CPS-reproductive wbpP complementation (Fig. 4). Moreover, the anti-TLR2 antibody blocked IL- 8 production and NF- $\kappa \mathrm{B}$ minimal promoter activity induced by the wild-type or the $w b p P$-complemented $V$. vulnificus, thus suggesting that the $V$. vulnificus CPS was involved in the TLR2-mediated IL-8 production of human epithelial cells exposed to V. vulnificus (Fig. 5). Finally, we evaluated the ability of purified $V$. vulnificus CPS to induce IL-8 production through a TLR2-dependent NF- $\mathrm{B}$ activation. The CPS was shown to significantly induce the expression of IL-8 and TLR2, as well as NF-кB activation. Importantly, pretreatment with the anti-TLR2 antibody resulted in a significant reduction in IL- 8 production in the INT-407 cells stimulated with the purified CPS. Also, antiTLR2 mAb pretreatment decreased NF- $\mathrm{kB}$ activation (Fig. 6). The importance of capsular polysaccharide in systemic inflammation has been previously reported in studies of $V$. vulnificus pathogenicity. Additionally, CPS production is believed to constitute a primary virulence factor of $V$. vulnificus, which is essential for pathogenicity $(5,22)$. The production of proinflammatory cytokines such as IL-1ß, TNF- $\alpha$, and IL-6 has been reported in $V$. vulnificus-infected hosts (12-14,40). Our data demonstrated that TLR2 is the key receptor for $V$. vulnificus CPS-related immune response. The role for the other TLRs in the production of other inflammatory cytokines in response to $V$. vulnificus should be investigated in further studies. Treatment with the anti-TLR2 mAb partially inhibited the $V$. vulnificus-mediated IL-8 expression, suggesting that, in addition to the CPS, other components of $V$. vulnificus are also involved in IL-8 production from INT407 cells exposed to $V$. vulnificus .

In conclusion, we established that the $V$. vulnificus capsular polysaccharide induces TLR2-dependent IL-8 production via the NF-кB activation pathway in human intestinal epithelial cells, and our results indicate that $V$. vulnificus CPS may be a key molecule in the modulation of $V$. vulnificus-mediated pathogenicity.

\section{Acknowledgements}

This study was supported by a grant of the Korea Healthcare Technology R\&D Project, Ministry of Health and Welfare, Republic of Korea (A080777).

\section{References}

1. Jones MK and Oliver JD: Vibrio vulnificus: disease and pathogenesis. Infect Immun 77: 1723-1733, 2009.

2. Strom MS and Paranjpye RN: Epidemiology and pathogenesis of Vibrio vulnificus. Microb Infect 2: 177-188, 2000.

3. Amaro C, Fouz B, Biosca EG, Marco-Noales E and Collado R: The polysaccharide $\mathrm{O}$ side chain of Vibrio vulnificus serogroup E is a virulence determinant for eels. Infect Immun 65: 2475-2479, 1997.

4. Powell JL, Wright AC, Wasserman SS, Hone DM and Morris JG Jr: Release of tumor necrosis factor alpha in response to Vibrio vulnificus capsular polysaccharide in vivo and in vitro models. Infect Immun 65: 3713-3718, 1997.

5. Wright AC, Powell JL, Kaper JB and Morris JG Jr: Identification of a group 1-like capsular polysaccharide operon for Vibrio vulnificus. Infect Immun 69: 6893-6901, 2001.

6. Wright AC, Powell JL, Tanner MK, Ensor LA, Karpas AB, Morris G Jr and Sztein MB: Differential expression of Vibrio vulnificus capsular polysaccharide. Infect Immun 67: 2250-2257, 1999.

7. Simpson LM and Oliver JD: Siderophore production by Vibrio vulnificus. Infect Immun 41: 644-649, 1983.

8. Gray LD and Kreger AS: Purification and characterization of extracellular cytolysin produced by Vibrio vulnificus. Infect Immun 48: 67-72, 1985.

9. Jeong KC, Jeong HS, Rhee JH, Lee SE, Chung SS, Starks AM, Escudero GM, Gulig PA and Choi SH: Construction and phenotypic evaluation of a Vibrio vulnificus vvpE mutant for elastolytic protease. Infect Immun 68: 5096-5106, 2000.

10. Testa J, Daniel LW and Kreger AS: Extracellular phospholipase A2 and lysophospholipase produced by Vibrio vulnificus. Infect Immun 45: 458-463, 1984.

11. Lee JH, Kim MW, Kim BS, Kim SM, Lee BC, Kim TS and Choi SH: Identification and characterization of the Vibrio vulnificus rtxA essential for cytotoxicity in vitro and virulence in mice. J Microbiol 45: 146-152, 2007.

12. Lee JH, Rho JB, Park KJ, Kim CB, HanYS, Choi SH, Lee KH and Park SJ: Role of flagellum and motility in pathogenesis of Vibrio vulnificus. Infect Immun 72: 4905-4910, 2004.

13. Espat NJ, Auffenberg T, Abouhamze A, Baumhofer J, Moldawer LL, and Howard RJ: A role for tumor necrosis factor- $\alpha$ in the increased mortality associated with Vibrio vulnificus infection in the presence of hepatic dysfunction. Ann Surg 223: 428-433, 1996.

14. Lee BC, Kim SH, Choi SH and Kim TS: Induction of interleukin- 8 production via nuclear factor- $\mathrm{\kappa} B$ activation in human intestinal epithelial cells infected with Vibrio vulnificus. Immunology 115: 506-515, 2005.

15. Hsieh YC, Liang SM, Tsai WL, Chen YH, Liu TY and Liang CM: Study of capsular polysaccharide from Vibrio parahaemolyticus. Infect Immun 71: 3329-3336, 2003.

16. Hayat U, Reddy GP, Bush CA, Johnson JA, Wright AC and Morris JG Jr: Capsular types of Vibrio vulnificus: an analysis of strains from clinical and environmental sources. J Infect Dis 168: 758-762, 1993.

17. Bush CA, Patel P, Gunawardena S, Powell J, Joseph A, Johnson JA and Morris JG Jr: Classification of Vibrio vulnificus strains by the carbohydrate composition of their capsular polysaccharides. Anal Biochem 250: 186-195, 1997.

18. Reddy GP, Hayat U, Abeygunawaradena C, Fox C, Wright AC, Maneval DR Jr, Bush CA and Morris JG Jr: Purification and determination of the structure of capsular polysaccharide of Vibrio vulnificus M06-24. J Bacteriol 174: 2620-2630, 1992. 
19. Smith A and Siebeling RJ: Identification of genetic loci required for capsular expression in Vibrio vulnificus. Infect Immun 71: 1091-1097, 2003.

20. Zuppardo AB and Siebeling RJ: An epimerase gene essential for capsule synthesis in Vibrio vulnificus. Infect Immun 66: 2601-2606, 1998.

21. Bleanger M, Burrows LL and Lam JS: Functional analysis of genes responsible for the synthesis of the $\mathrm{B}$-band $\mathrm{O}$ antigen of Pseudomonas aeruginosa serotype O6 lipopolysaccharide. Microbiology 145: 3505-3521, 1999.

22. Park NY, Lee JH, Kim MW, Jeong HG, Lee BC, Kim TS and Choi SH: Identification of the Vibrio vulnificus $w b p P$ gene and evaluation of its role in virulence. Infect Immun 74: 721-728, 2006.

23. Sharma SA, Tummuru MK, Blaser MJ and Kerr LD: Activation of IL-8 gene expression by Helicobacter pylori is regulated by transcription factor nuclear factor-kappa B in gastric epithelial cells. J Immunol 160: 2401-2407, 1998.

24. Ishihara S, Rumi MA, Kadowaki Y, Ortega-Cava CF, Yuki T, Yoshino N, Miyaoka Y, Kazumori H, Ishimura N, Amino Y and Kinoshita Y: Essential role of MD-2 in TLR4-dependent signaling during Helicobacter pylori-associated gastritis. J Immunol 173: 1406-1416, 2004.

25. Yu Y, Zeng H, Lyons S, Carlson A, Merlin D, Neish AS and Gewirtz AT: TLR5-mediated activation of p38 MAPK regulates epithelial IL-8 expression via posttranscriptional mechanism. Am J Physiol Gastrointest Liver Physiol 285: G282-G290, 2003.

26. Abreu MT, Fukata M and Arditi M: TLR signaling in the gut in health and disease. J Immunol 174: 4453-4460, 2005.

27. Nishimura $M$ and Naito $S$ : Tissue-specific mRNA expression profiles of human Toll-like receptors and related genes. Biol Pharm Bull 28: 886-892, 2005.

28. Lee BC, Lee JH, Kim MW, Kim MC, Oh MW, Kim KS Kim TS and Choi SH: Vibrio vulnificus rtxE is important for virulence, and its expression is induced by exposure to host cells. Infect Immun 76: 1509-1517, 2008.

29. Enos-Berlage JL and McCarter LL: Relation of capsular polysaccharide production and colonial cell organization to colony morphology in Vibrio parahaemolyticus. J Bacteriol 182: 5513-5520, 2000

30. Jung YD, Fan F, McConkey DJ, Jean ME, Liu W, Reinmuth N, Stoeltzing O, Ahmad SA, Parikh AA, Mukaida N and Ellis LM: Role of p38 MAPK, AP-1, and NF-кB in interleukin-1ß-induced IL-8 expression in human vascular smooth muscle cells. Cytokine 18: 206-213, 2002.
31. Matsusaka T, Fujikawa K, Nishio Y, Mukaida N, Matsushima K, Kishimoto $\mathrm{T}$ and Akira S: Transcription factors NF-IL6 and $\mathrm{NF}-\kappa \mathrm{B}$ synergistically activate transcription of the inflammatory cytokines, interleukin-6 and interleukin-8. Proc Natl Acad Sci USA 90: 10193-10197, 1993.

32. Haller D, Holt L, Parlesak A, Zanga J, Baueriein A and Jobin C: Differential effect of immune cells on non-pathogenic Gramnegative bacteria induced nuclear factor- $\mathrm{K} \mathrm{B}$ activation and proinflammatory gene expression in intestinal epithelial cells. Immunology 112: 310-320, 2004.

33. Hosoi T, Hirose R, Saegusa S, Ametani A, Kiuchi K and Kaminogawa $\mathrm{S}$ : Cytokine responses of human intestinal epithelial-like Caco-2 cells to the nonpathogenic bacterium Bacillus subtilis (natto). Int J Food Microbiol 15: 255-264, 2003.

34. Goo SY, Han YS, Kim WH, Lee KH and Park SJ: Vibrio vulnificus IIpA-induced cytokine production is mediated by Toll-like receptor 2. J Biol Chem 282: 27647-27658, 2007.

35. Duenas AI, Orduna A, Crespo MS and Garcia-Rodriguez C: Interaction of endotoxins with Toll-like receptor 4 correlates with their endotoxic potential and may explain the proinflammatory effect of Brucella spp LPS. Int Immunol 16: 1467-1475, 2004.

36. Mitsuzawa H, Nishitani C, Hyakushima N, Shimizu T, Sano H, Matsushima N, Fukase K and Kuroki Y: Recombinant soluble forms of extracellular TLR4 domain and MD-2 inhibit lipopolysaccharide binding on cell surface and dampen lipopolysaccharide-induced pulmonary inflammation in mice. J Immunol 177: 8133-8139, 2006.

37. Wullt B, Bergsten G, Connell H, Rollano P, Gebratsedik N, Hang L and Svanborg C: P-fimbriae trigger mucosal responses to Escherichia coli in the human urinary tract. Cell Microbiol 3: 255-264, 2001.

38. Urban TA, Griffith A, Torok AM, Smolkin ME, Burns JL and Goldberg JB: Contribution of Burkholderia cenocepacia flagella to infectivity and inflammation. Infect Immun 72: 5126-5134, 2004.

39. Yu Y, Nagai S, Wu H, Neish AS, Koyasu S and Gewirtz AT: TLR5-mediated phosphoinositide 3-kinase activation negatively regulates flagellin-induced proinflammatory gene expression. J Immunol 176: 6194-6201, 2006.

40. Lee SE, Kim SY, Jeong BC, Kim YR, Bae SJ, Ahn OS, Lee JJ Song HC, Kim JM, Choy HE, Chung SS, Kweon MN and Rhee JH: A bacterial Flagellin, Vibrio vulnificus FlaB, has a strong mucosal adjuvant activity to induce protective immunity. Infect Immun 74: 694-702, 2006. 